\title{
Högskolans språk och mitt eget. En studie av nyantagna lärarstudenters förhållningssätt till skrivande, skriftspråket på högskolan och den egna skrivkompetensen
}

\author{
Emilia Sturm Aldrin*, Monica Eklund och Heike Peter \\ Högskolan i Halmstad
}

\begin{abstract}
This article explores how a heterogenous group of first year university students perceive writing in general, academic writing in specific, as well as their own writing proficiency. A questionnaire ( $\mathrm{n}$ 93) was created basing on theories on academic literacy and writing psychology. The results show varying attitudes among the students which highlight questions of the dimensions of writing, identity and group affiliations. Gender was of little importance, whereas age and self-stated writing skills correlated to some extent with the results. The small scale of the study does not permit far-reaching conclusions, but the results indicate attitudes that could have importance for the development of academic literacy. The study can be used as a start of departure for interventions that facilitate for groups with different backgrounds to participate in higher education.
\end{abstract}

Keywords: Academic writing, attitudes, motivation, identity, widening participation

\section{INLEDNING}

Högskolestudenters utveckling av färdigheter i akademisk kommunikation är en aktuell fråga som diskuteras vid många lärosäten, inte minst i relation till den så kallade breddade rekryteringen. Universitetskanslerämbetet (UKÄ, 2018) betonar att det är viktigt med hög genomströmning på yrkesexamensutbildningar. Annars används lärosätenas resurser inte på ett optimalt sätt och på individnivå innebär avhopp att studenten inte når sitt mål. Lärosäten som arbetar med breddad rekrytering måste därför också tillse breddat deltagande. Eftersom studenter från studieovana hem ofta saknar de hem- och familjerelaterade koder som annars kan underlätta övergången till högre utbildning (Walker, 2006) tenderar den akademiska kommunikationen att bli en särskilt påtaglig flaskhals (Middendorf \& Pace, 2004). För att breddad rekrytering ska kunna leda till att de rekryterade också fullföljer sin utbildning behöver denna flaskhals reduceras. I den här artikeln undersöker vi hur nyantagna lärarstudenter förhåller sig till det akademiska skriftspråket och det egna skrivandet, vilket vi menar är viktigt för att på ett framgångsrikt sätt planera stöttande metoder.

Akademisk kommunikation utgör ett omfattande och komplext internationellt forskningsfält med flera inriktningar som definierar forskningsfokus, teori och metod på olika sätt. Den här studien placerar sig inom inriktningen Academic literacies (Lea \& Street, 2006; Duff, 20Io; Lillis, Harrington, Lea \& Mitchell, 20I6) som betonar att de processer genom vilka studenter

\footnotetext{
*Korrespondens: emilia.aldrin@hh.se
} 
utvecklar kompetenser inom akademisk kommunikation påverkas av de sociala processer, maktrelationer och identitetsskapande som pågår inom ett akademiskt fält. Inriktningen är teoretiskt influerad av såväl sociolingvistik och kritisk diskursanalys som etnografi och sociokulturell lärandeteori (Lea \& Street, 2006). När studenter introduceras i akademiska kommunikativa praktiker sker detta genom såväl modeller som respons från lärare, studentens eget engagemang, förhandling av maktrelationer och identiteter samt, för vissa, genom viktig personlig förändring (Duff, 20IO).

Inom den svenska forskningen har flera studier, i likhet med vår, fokuserat på lärarstudenters akademiska språkutveckling. En viktig problematisering i sammanhanget har framförts av Malmbjer (20I7) som hävdar att svenska lärarstudenter ofta möter flera olika ämnesspråk och textnormer under en och samma termin, vilket skapar en särskild utmaning. Ask har i flera studier analyserat så kallade "stadieövergångar" vid studenters inträde på lärarutbildningen (Ask, 2005a, 2005b, 2007; Ask \& Sandblad, 2003) och finner att många studenter saknar viktiga kunskaper om den diskurs de skriver i, vilket skapar en "diskurschock" (Ask, 2005a, s. 89) som försvåras av att de akademiska normerna ofta förblir outtalade eller oklara och tycks omges av en "hemlighetskultur" (Ask, 2007, s. 17I). Ask (2005b) har också studerat hur övergången från gymnasium till högskola upplevs på delvis olika sätt beroende på kön och tidigare vald studieinriktning (yrkesförberedande respektive studieförberedande gymnasieprogram). Studenter som gått studieförberedande program på gymnasiet visade sig vara mer nöjda med den tidigare undervisningen i svenska än studenter som gått yrkesförberedande program. De senare - och särskilt män i denna grupp - upplevde också fler svårigheter med språkliga aktiviteter på högskolan medan kvinnorna upplevde färre, vilket föreslås hänga samman med att kvinnorna i högre grad tyckte sig ha tillgång till stöttning från omgivningen, genom familjen eller någon annan som har erfarenhet av akademiska studier. Ask (2007) betonar att "individers skriftspråkshistoria och sociokulturella bakgrund" (s. I7I) är nyckelfaktorer för utvecklingen av ett akademiskt skriftspråk och att studenters förutsättningar för att internalisera detta behöver utforskas ytterligare. Även Arneback, Englund och Dyrdal Solbrekke (2016) framhäver att studenters tidigare livserfarenheter är betydelsefulla och bör uppmärksammas och användas mer i samband med den akademiska skrivutvecklingen, men lyfter dessutom fram att deras relevans kan förändras över tid. Ett liknande resonemang förs av Erixon och Erixon Arreman (2019) som har följt ett antal förskollärarstudenter som är de första i sin familj att genomföra högskolestudier och finner att de långt fram i utbildningen uttrycker tveksamhet över att se sig som del av en större akademisk gemenskap, vilket tycks sammanfalla med upplevda skrivsvårigheter. Studier från andra länder (se t.ex. Tapp, 20I4) visar emellertid att arbetarklasstudenter också kan vara ivriga att konstruera en identitet som akademiker och att detta inte behöver innebära ett avståndstagande från en arbetaridentitet, utan kan ske genom skapande av hybridformer.

En annan viktig utgångspunkt för denna studie är den teoretiska uppfattningen att individers attityder till språk kan ha betydelse som drivkraft för språklig variation och förändring (Kristiansen, 2009). Begreppet "attityd" definieras ofta som ett socialt inlärt men relativt varaktigt reaktionsmönster på ett visst fenomen (Garrett, 20Io). På grund av studiens begränsade omfång har varaktigheten i studenternas attityder till det akademiska språkbruket inte kunnat studeras och därför används här istället begreppet "förhållningssätt". Attityder är komplexa fenomen och inbegriper samverkan mellan såväl en kognitiv komponent (föreställningar som kan vara mer eller mindre sanna), en affektiv komponent (känslomässiga värderingar) och beteende (inklusive handlingsberedskap) (Garrett, 20IO). Komponenterna kan samverka på 
olika sätt och det är inte ovanligt att det finns motsättningar mellan exempelvis en persons kognitiva och affektiva förhållningssätt respektive personens faktiska agerande. Det innebär att det inte går att förutse beteende på något enkelt sätt enbart utifrån kunskap om attityder. Attityders betydelse har under senare år lyfts fram i internationella skrivteorier baserade på utbildningspsykologi. Graham (2006; Graham, Daley, Aitken, Harris \& Robinson, 2018) visar att motivationen att utveckla det egna skrivandet påverkas av individens attityder, såväl till skrivande generellt som till specifika skrivuppgifter och skrivkontexter. Studentens självförtroende som skribent är en annan faktor som visat sig betydelsefull för motivationen att utveckla skrivandet (Troia, Shankland \& Wolbers, 20I2). Inom forskningen om språkattityder har det vidare poängterats att människor har svårt att särskilja sin attityd till språkliga uttryck från attityden till de talare som förknippas med språket (Ryan, Giles \& Sebastian, 1982). Språk som förknippas med människor med hög status skapar ofta positiva attityder hos många, samtidigt som språk som förknippas med människor som vi känner grupptillhörighet och solidaritet med också skapar positiva attityder (oavsett status). Detta ger en intressant utgångspunkt när det gäller studenters attityder till akademiskt språk som förknippas med en social grupp (akademiker och universitetslärare) som studenter i varierande grad kan uppleva samhörighet med i början av sin utbildning.

Sammantaget innebär detta att vi i denna studie betraktar akademiskt skrivande som ett i hög grad komplext fenomen som utvecklas i samverkan med andra sociala processer. Vi riktar särskilt fokus mot hur studenter identifierar sig som skribenter och vilka förhållningssätt studenter uttrycker i relation till skrivande, vilket föreslagits vara viktiga komponenter för motivation till skrivutveckling, men som i Sverige sällan undersökts inom ramen för skrivande på akademisk nivå. Till skillnad från tidigare studier undersöker vi också samverkan mellan dessa faktorer samt vilken betydelse studentens ålder och kön kan få i sammanhanget.

\section{SYFTE OCH FRÅGESTÄLLNINGAR}

Syftet med denna artikel är att undersöka vilka förhållningssätt nya lärarstudenter uttrycker till högskolans språk och det egna skrivandet, samt att diskutera vilka förutsättningar detta kan skapa för den fortsatta utvecklingen av färdigheter i akademiskt skrivande. Detta sker i enlighet med den tidigare forskningens betoning på att man behöver undersöka studenters meningsskapande processer liksom attityder till och tidigare erfarenhet av skrivande för att kunna utveckla framgångsrika stöttande metoder. Genom en enkätundersökning som möjliggör kvantitativ korrelation samt kvalitativ analys av öppna svar vill vi undersöka vilka förhållningssätt som kan framkomma i en heterogen studentgrupp vid ett mindre svenskt lärosäte. Mer specifikt undersöks följande frågeställningar:

- Vilka förhållningssätt till skrivande generellt och akademiskt skrivande mer specifikt finns i en grupp med nyantagna lärarstudenter?

- Hur upplever nyantagna lärarstudenter den egna skrivförmågan?

- Framkommer det några samband mellan studenters kön, ålder, tilltro till egen skrivförmåga och förhållningssätt till akademiskt skrivande?

\section{FORSKNINGSDESIGN}

Studien har sin bakgrund i ett tvärvetenskapligt forskningsprojekt med anslutning till en genomförd kvalitetssatsning inom ämneslärarutbildningen vid ett mindre lärosäte. Företrädare för olika ämnen identifierade likartade svårigheter hos studenter vid produktion av akademisk 
text, vilket gav upphov till en högskolepedagogisk intervention och ett forskningsprojekt, där denna artikel utgör den första delstudien ${ }^{\mathrm{I}}$.

En enkätundersökning riktades till samtliga nya studenter på grund- och ämneslärarutbildningarna vid Högskolan i Halmstad hösten 2017. Enkäten delades ut i samband med ett frivilligt lektionspass om akademiskt skrivande, som var del av den högskolepedagogiska intervention som ska analyseras vidare inom kommande delar av forskningsprojektet. Vid det aktuella lektionstillfället, i mitten av september 20I7, deltog II studenter varav 93 valde att besvara enkäten. Enkäten delades ut i början av lektionen och studenterna fick information om att resultaten skulle användas både för att kunna anpassa undervisningen på kommande moment $\mathrm{i}$ interventionen och som del av ett forskningsprojekt, samt att deltagande var helt frivilligt och anonymt. Läraren som delade ut enkäten var inte examinator för någon av studenterna. Det finns en svag övervikt av kvinnliga studenter bland deltagarna (60\%), majoriteten av studenterna är 2I-26 år (56\%), medan studenter i åldern $\leq 20$ år och $\geq 27$ år är betydligt färre (2I \% respektive $23 \%$ ). I högskolans årliga rekryteringsenkät i samband med terminsstarten framgår att det i de aktuella studentgrupperna finns olika språkliga bakgrunder representerade, studenter med svensk respektive utländsk bakgrund liksom många studenter från studieovana hem.

Vår enkät innehöll sex frågor om studentens förhållningssätt till skrivande generellt, skrivandet på högskolan och den egna skrivkompetensen. Därmed är det genomgående i första hand studenternas explicita och medvetna förhållningssätt som efterfrågas. Dessutom fanns två bakgrundsfrågor i enkäten om studentens kön och ålder som möjliggör en inledande analys av hur studenternas förhållningssätt samvarierar med dessa faktorer. Däremot är materialet alltför begränsat för att multivariat analys ska vara möjlig. Ytterligare bakgrundsvariabler såsom flerspråkighet och studievana i hemmet fokuseras i senare delar av projektet. Fyra enkätfrågor var i hög grad strukturerade med bundna svarsalternativ för att möjliggöra kvantitativ analys, medan två frågor var öppna och lät studenten formulera ett svar med egna ord för att möjliggöra ett kvalitativt inslag i analysen. Det finns ett visst internt bortfall som nästan uteslutande rör de öppna frågorna. Den första öppet formulerade frågan har besvarats av alla utom två studenter ( $2 \%$ bortfall), men den andra öppna frågan har hoppats över av I2 studenter (I3 \% bortfall).

FÖRHÅLLNINGSSÄTT TILL SKRIVANDE GENERELLT OCH EGEN SKRIVFÖRMÅGA Studenternas övergripande förhållningssätt till skrivande undersöktes med frågan: Vad är din generella inställning till skrivande? Genom svarsalternativen uppmanades deltagarna att beskriva sitt känslomässiga förhållningssätt i termer av "tycker om" eller "tycker inte om" att skriva. Dessutom erbjöds ett neutralt svarsalternativ "varken eller". Resultatet (diagram I) visar att hälften av de nyantagna lärarstudenterna (47 av 93 st. eller 5I \%) uttrycker ett positivt förhållningssätt till skrivande, medan mycket få uttrycker ett negativt förhållningssätt. Troligen finns här en viss forskareffekt så att en del studenter uttrycker sig mer positivt i frågan än de kanske skulle ha gjort i ett annat sammanhang, men det är ändå intressant att varannan student i gruppen har kommit till lärarutbildningen med grundinställningen att de tycker om att skriva. Samtidigt har en stor andel angett ett neutralt svar (44\%), vilket tyder på att de inte upplever något känslomässigt förhållningssätt till skrivande överhuvudtaget. Enbart fem studenter ( $5 \%)$ tycker inte om att skriva.

\footnotetext{
${ }^{1}$ Denna delstudie har huvudsakligen genomförts av Emilia Aldrin, men de båda andra artikelförfattarna har bidragit med viktiga inspel i såväl planering som analys och textbearbetning.
} 


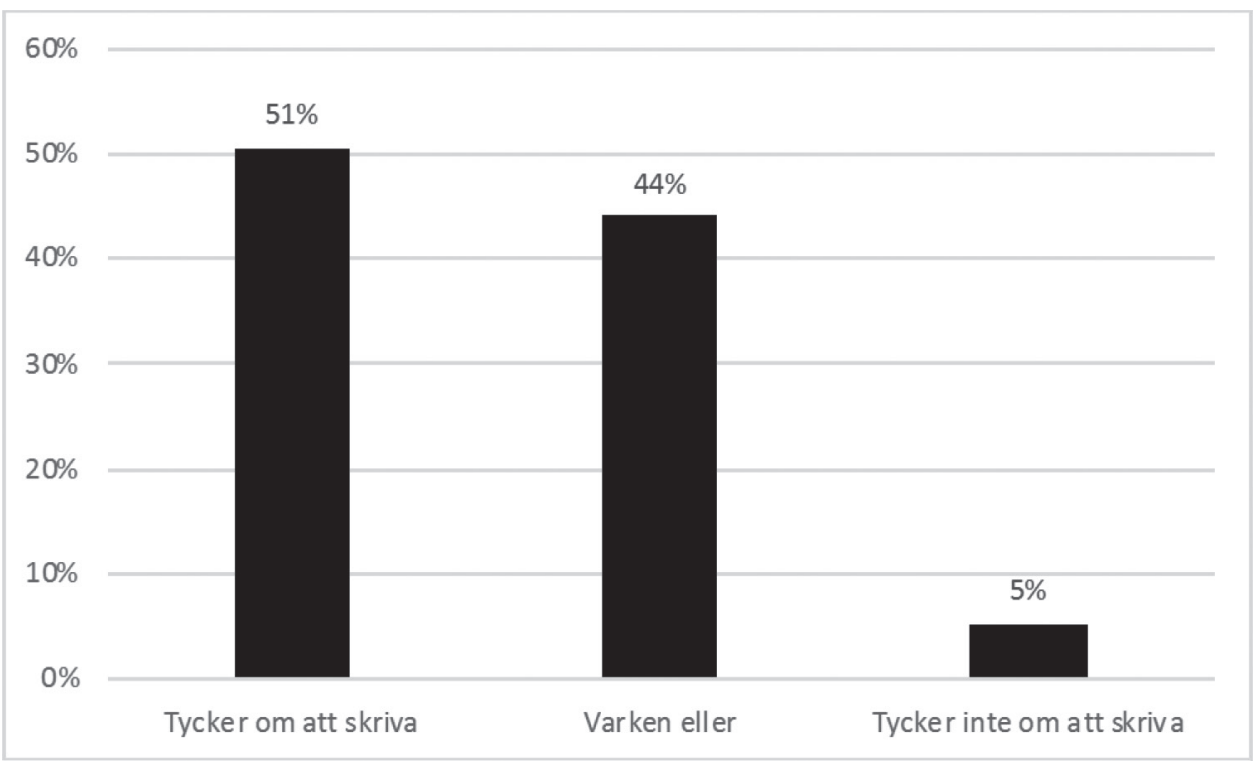

Diagram I. Studenternas generella inställning till skrivande (redovisat i procent, $n=93$ ).

Det är vanligare att kvinnliga studenter ger uttryck för att de tycker om att skriva (6I \%) än att manliga studenter gör det (35\%), vilket framgår av tabell $\mathrm{I}$. Istället är det fler manliga studenter som uttrycker ett neutralt förhållningssätt $(54 \%)$. Intressant är också att fyra av de fem studenter som uttrycker att de inte tycker om att skriva är män. De sammantagna skillnaderna med avseende på studentens kön är statistiskt signifikanta. ${ }^{2}$

Tabell ${ }_{I}$. Generell inställning till skrivande, sett i relation till studentens kön (redovisat $i$ absoluta frekvenser och procent).

\begin{tabular}{lccc}
\hline & Kvinnor & Män & Totalt \\
\hline Tycker om att skriva & $34(6 \mathrm{I} \%)$ & $\mathrm{I3}(35 \%)$ & $47(5 \mathrm{I} \%)$ \\
Varken eller & $2 \mathrm{I}(37 \%)$ & $20(54 \%)$ & $4 \mathrm{I}(44 \%)$ \\
Tycker inte om att skriva & I (2\%) & $4(\mathrm{II} \%)$ & $5(5 \%)$ \\
Totalt & $\mathbf{5 6}($ Ioo \%) & $\mathbf{3 7}($ I00 \%) & $\mathbf{9 3}$ (100\%) \\
\hline
\end{tabular}

I förhållande till ålder (tabell 2) visar det sig att de äldsta studenterna, som är 27 år eller äldre, uttrycker det mest positiva förhållningssättet till skrivande; här har $76 \%$ svarat att de tycker om att skriva. Bland studenter 2I-26 år är det enbart $36 \%$ som är lika positiva och här finns också något fler som inte tycker om att skriva ( $8 \%$ eller 4 st.), men de flesta uttrycker ett neutralt förhållningssätt. Skillnaderna utifrån ålder är statistiskt signifikanta. ${ }^{3}$

\footnotetext{
2 X2-analys ger Pearson X2 7,645, DF 2, p 0,022.

3 X2-analys ger Pearson X2 11,386, DF 4, p 0,023.
} 
Tabell 2. Generell inställning till skrivande, sett i relation till studentens ålder (redovisat $i$ absoluta frekvenser och procent).

\begin{tabular}{|c|c|c|c|c|}
\hline & $\leq \mathbf{2 0}$ år & $21-26$ år & $\geq 27$ år & Totalt \\
\hline Tycker om att skriva & I2 $(60 \%)$ & I9 $(36 \%)$ & I6 (76\%) & $47(5 \mathrm{I} \%)$ \\
\hline Varken eller & $8(40 \%)$ & $29(56 \%)$ & $4(19 \%)$ & 4I $(44 \%)$ \\
\hline Tycker inte om att skriva & - & $4(8 \%)$ & I $(5 \%)$ & $5(5 \%)$ \\
\hline Totalt & $20(100 \%)$ & $52(100 \%)$ & $21(100 \%)$ & $93($ (ооо \%) \\
\hline
\end{tabular}

Studenternas tilltro till sin egen förmåga som skribenter är på liknande sätt försiktigt positiv, vilket visas i diagram 2. Svarsalternativen var här "jag är generellt bra på att skriva", "jag är generellt inte så bra på att skriva" samt "varken eller". Lika stor andel angav något av de två första alternativen ( $42 \%$ ), medan en mindre andel angav det tredje alternativet (I6\%). Här beskriver studenterna alltså inte sitt känslomässiga förhållningssätt, utan gör en bedömning av sin egen förmåga. En relativt hög andel (42\%) visar god tilltro till den egna skrivförmågan, men var sjätte student visar låg tilltro. En korrelation med studenternas känslomässiga förhållningssätt visar att det inte är alla som tycker om att skriva som också tycker att de är bra på det. Likaså är det fler som uttrycker att de inte är så bra på att skriva än som uttrycker att de inte tycker om att skriva. Studenternas kön och ålder ger inte upphov till några statistiskt signifikanta mönster här.



Diagram 2. Studenternas tilltro till den egna skrivförmågan (redovisat i procent, $n=93$ ).

\section{FÖRHÅLLNINGSSÄTT TILL AKADEMISKT SKRIVANDE}

Flera enkätfrågor var specifikt inriktade på studenternas förhållningssätt till akademiskt skrivande. På frågan om huruvida studenterna har en tydlig bild av vad det innebär att "skriva akademiskt" visar det sig att majoriteten vid denna tidpunkt ett par veckor in på första terminen inte tycker sig ha det (diagram 3). Svaren centrerar sig kring mittenalternativen, men betydligt fler har svarat "inte så tydlig" ( 50 av 93 st. eller 54 \%) än "ganska tydlig" (37 \%). Kön och ålder tycks inte påverka. 


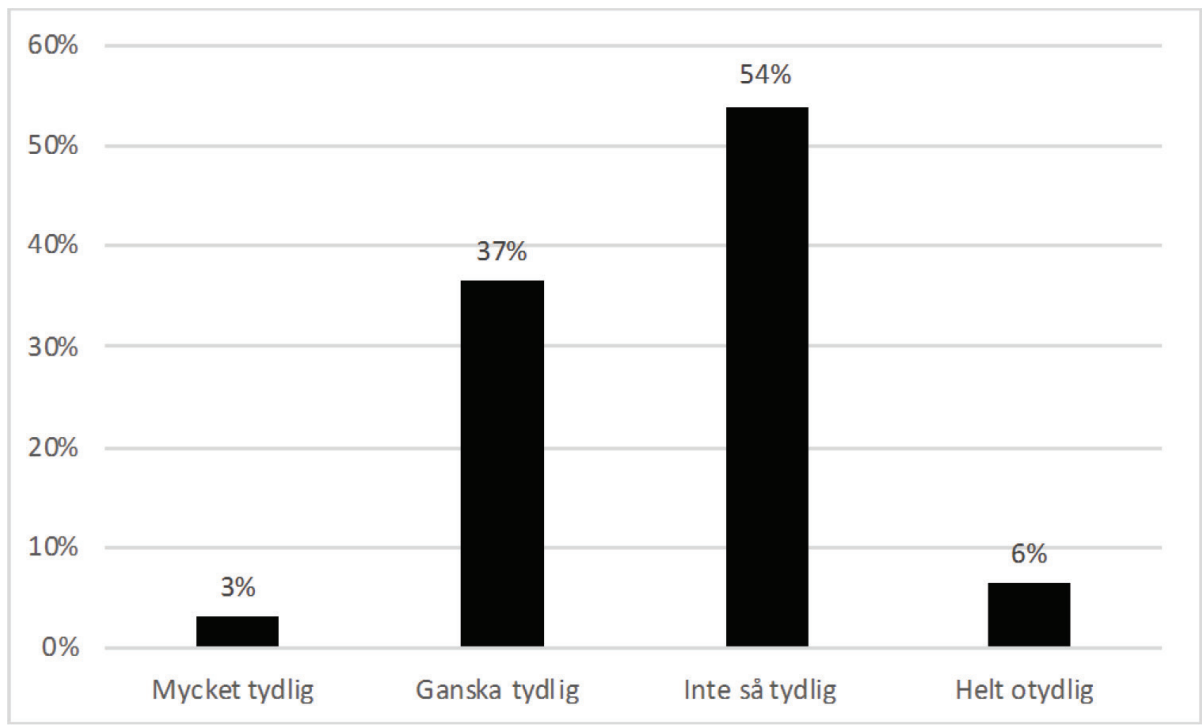

Diagram 3. Studenternas upplevelse av hur tydlig bild de har av vad det innebär att "skriva akademiskt" (redovisat i procent, $n=93$ ).

Trots att studenterna enbart gått på högskolan i ett par veckor och många har en otydlig bild av vad det innebär att "skriva akademiskt" uppger de allra flesta att de redan har förändrat sitt sätt att skriva (diagram 4). Hela 87 \% tycker sig ha förändrat sitt sätt att skriva i någon mån efter starten på högskolan, men de flesta bara lite. Endast I3 \% (I2 personer) upplever att de inte förändrat sitt sätt att skriva överhuvudtaget.

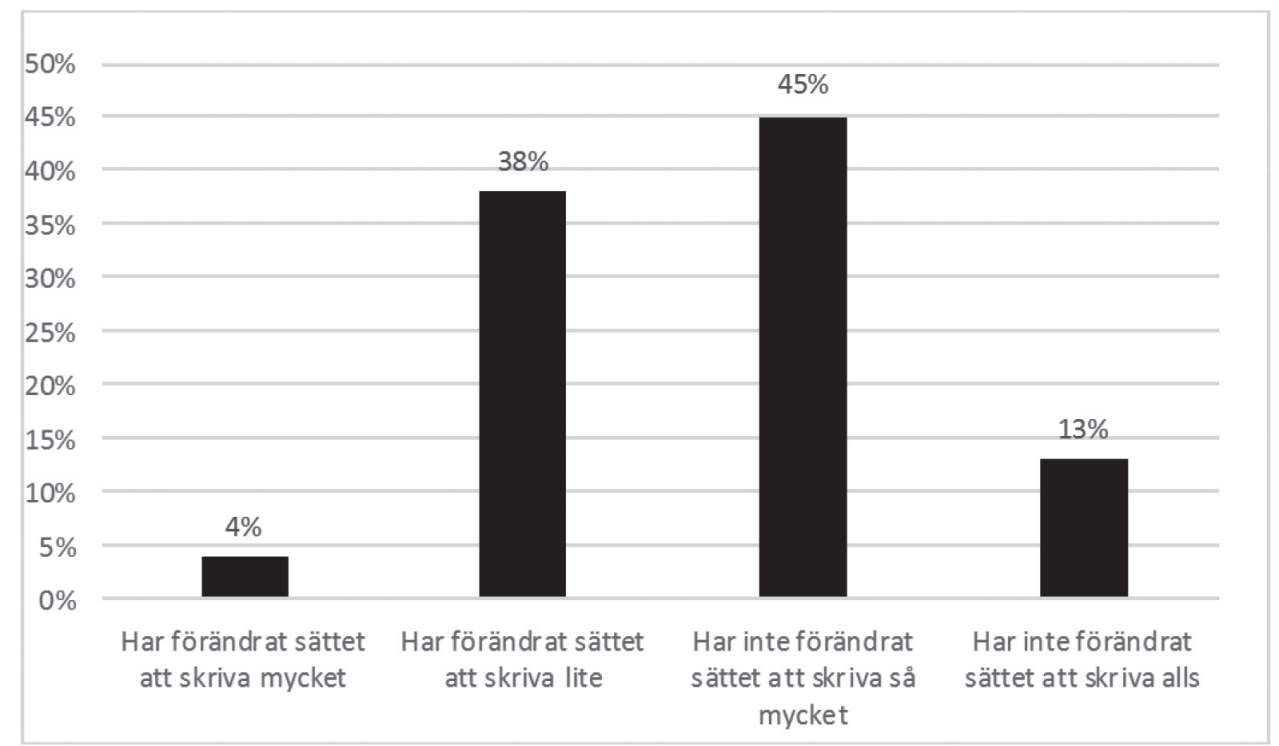

Diagram 4. Studenternas självskattade förändring av sättet att skriva efter start på högskolan (redovisat i procent, $n=93$ ). 


\section{Emilia Sturm Aldrin et al.}

Det framkommer inga större skillnader mellan kvinnor och män i detta avseende, däremot får studenternas ålder viss betydelse, vilket visas i tabell 3 .

Tabell 3. Upplevd förändring av sättet att skriva efter start på högskolan, sett i relation till studentens ålder (redovisat $i$ absoluta frekvenser och procent).

\begin{tabular}{|c|c|c|c|c|}
\hline & $\leq 20$ àr & $21-26$ år & $\geq 27$ år & Totalt \\
\hline Har förändrat skrivandet mycket & - & I $(2 \%)$ & $3(\mathrm{I} 4 \%)$ & $4(4 \%)$ \\
\hline Har förändrat skrivandet lite & $4(20 \%)$ & $24(46 \%)$ & $7(33 \%)$ & $35(38 \%)$ \\
\hline Har inte förändrat skrivandet så mycket & $\mathrm{I} 4(70 \%)$ & $22(42 \%)$ & $6(29 \%)$ & $42(45 \%)$ \\
\hline Har inte förändrat skrivandet alls & $2(\mathrm{IO} \%)$ & $5(\mathrm{IO} \%)$ & $5(24 \%)$ & I2 (I3 \%) \\
\hline Totalt & $20(100 \%)$ & $52(100 \%)$ & $21(100 \%)$ & $93($ (100\%) \\
\hline
\end{tabular}

De äldsta studenterna (som är 27 år eller äldre) skiljer sig från övriga genom att här både finns fler som tycker sig ha förändrat sitt skrivande mycket och fler som inte tycker sig ha förändrat skrivandet alls. Yngre studenter har istället i högre grad uppgett mittenalternativen. Åldersskillnaderna är statistiskt signifikanta. ${ }^{4}$

I en öppen fråga uppmanades studenterna att fundera över hur de tycker att man ska "skriva för att det ska bli akademiskt (passa i högskoleutbildningen)" och skriva ned det första ord de kom på. Studenternas svar har grupperats i fyra huvudsakliga semantiska fält, vilket visas i tabell 4. Några svar kan kopplas till mer än ett semantiskt fält, varför den totala summan i tabellen (98) överstiger antal svarande på frågan (9I). Två studenter har inte angett något ord.

\section{Tabell 4. Studenternas uppfattningar om hur man ska skriva för att det ska bli} "akademiskt", grupperat i semantiska fält (n 9I).

\begin{tabular}{|c|c|c|c|c|}
\hline Språklig formulering & $\begin{array}{l}\text { Förhållnings- } \\
\text { sätt till innehåll }\end{array}$ & $\begin{array}{l}\text { Struktur och } \\
\text { tydlighet }\end{array}$ & Källhantering & Övrigt \\
\hline $\begin{array}{l}\text { formellt (II), korrekt (7), } \\
\text { avancerat (4), fina ord (2), } \\
\text { krångligt (2), } \\
\text { professionella ord (2), } \\
\text { smart (2), vuxet (2), } \\
\text { väl formulerat (2), } \\
\text { bra formulerat (I), } \\
\text { ej vardagligt (I), ingen } \\
\text { slang (I), ordentligt (I), } \\
\text { omformulera meningar (I), } \\
\text { pretentiöst (I), stelt (I), } \\
\text { svårordigt (I), svårt (I) }\end{array}$ & $\begin{array}{l}\text { utförligt (7), } \\
\text { nyanserat (5), } \\
\text { informativt (2), } \\
\text { utvecklat (2), } \\
\text { analyserande (I), } \\
\text { informerande (I), } \\
\text { informationsgivande (I), } \\
\text { objektivt (I), } \\
\text { opersonligt (I), } \\
\text { reflekterande (I), } \\
\text { vara kritisk (I), } \\
\text { värderingsfritt (I) }\end{array}$ & $\begin{array}{l}\text { struktur (7), } \\
\text { tydligt (6), } \\
\text { förståeligt (3), } \\
\text { röd tråd (I) }\end{array}$ & $\begin{array}{l}\text { referat (3), } \\
\text { angiven källa (I) }\end{array}$ & $\begin{array}{l}\text { vetenskapligt (5), } \\
\text { använd ämnesord (I), } \\
\text { politiskt korrekt (I), } \\
\text { relevant (I), } \\
\text { unikt (I), } \\
\text { utbildnings- } \\
\text { inriktat (I), } \\
\text { vältänkt (I) }\end{array}$ \\
\hline Totalt: 42 st. & Totalt: 24 st. & Totalt: 17 st. & Totalt: 4 st. & Totalt: II st. \\
\hline
\end{tabular}

En första stor grupp av svaren (46 \%) berör språklig formulering och särskilt stilnivå. Här återfinns en mångfald av ord såsom formellt, avancerat, stelt, krängligt, svårordigt, professionellt, fina ord, smart och pretentiöst. En andra grupp svar $(27 \%)$ berör hur skribenten handskas med innehållet, vilket vi sammanfattande beskriver som förhållningssätt till innehåll. Här återfinns

${ }^{4}$ X2-analys ger Pearson X2 15,778, DF 6, p 0,015. 
ord såsom informationsgivande, informativt och utförligt, men också opersonligt, reflekterande och vara kritisk. En tredje grupp (I9 \%) uttrycker konnotationer som berör den akademiska textens struktur och tydlighet: förståeligt, röd tråd, struktur och tydligt. En fjärde grupp svar (4 \%) berör källhantering: angiven källa och referat. Det förekommer också enstaka övriga svar (I2 \%) såsom relevant, vältänkt, använd ämnesord, vetenskapligt (som kan ses som en synonym till ordet "akademiskt" i frågeställningen) men också politiskt korrekt, unikt och utbildningsinriktat. Inga statistiskt signifikanta skillnader uppkommer i relation till kön eller ålder.

I en annan öppen fråga fick studenterna formulera vad de upplever som mest svårt med att skriva inom högskoleutbildning (återigen med ett enda ord). Även här har svaren kategoriserats utifrån semantiska fält (se tabell 5 ) och i ett fall ansluter samma svar till flera fält. I2 studenter har inte angett något ord.

Tabell 5 . Studenternas uppfattningar om svairigheter med att skriva texter inom högskoleutbildning, grupperat i semantiska fält (n 8I).

\begin{tabular}{|c|c|c|c|c|}
\hline Källhantering & $\begin{array}{l}\text { Struktur och } \\
\text { tydlighet }\end{array}$ & Språklig formulering & $\begin{array}{l}\text { Förhållnings- } \\
\text { sätt till innehåll }\end{array}$ & Övrigt \\
\hline $\begin{array}{l}\text { referenser (9), } \\
\text { referera (5), } \\
\text { att formulera om } \\
\text { så det inte blir för } \\
\text { kopierat (I), fakta (I), } \\
\text { källor/böcker (I), } \\
\text { regler (I), reglerna } \\
\text { kring hur det ska se } \\
\text { ut (I) }\end{array}$ & $\begin{array}{l}\text { struktur (7), } \\
\text { sammanhang (3), } \\
\text { längden (2), } \\
\text { tydlighet (2), } \\
\text { flytet (I), } \\
\text { röda tråden (I), } \\
\text { uppdelningen } \\
\text { mycket fakta på } \\
\text { lite ord (I), } \\
\text { veta när man } \\
\text { ska sluta (I) }\end{array}$ & $\begin{array}{l}\text { formulera sig (4), } \\
\text { korrekt (2), menings- } \\
\text { byggnad (2), ordval (2), } \\
\text { akademiska ord (I), } \\
\text { använda korrekt } \\
\text { svenska (I), avancerat } \\
\text { ordförråd (I), begrepp (I), } \\
\text { grammatiken (I), svåra } \\
\text { ord (I) }\end{array}$ & $\begin{array}{l}\text { analyserande text (I), } \\
\text { djup (I), egna } \\
\text { åsikter (I), inte } \\
\text { ha med egna } \\
\text { värderingar (I), kritisk } \\
\text { sammanfattning (I), } \\
\text { nyanserat (I), } \\
\text { objektivitet (I), } \\
\text { opersonligt (I), } \\
\text { saklighet (I) }\end{array}$ & $\begin{array}{l}\text { akademiskt (3), } \\
\text { början (3), } \\
\text { komplicerat (2), } \\
\text { tentor (2), } \\
\text { vetenskapligt (2), } \\
\text { idétorka (I), } \\
\text { kreativitet (I), de } \\
\text { olika skrivsätten (I), } \\
\text { komplext (I), } \\
\text { ansträngande (I), } \\
\text { svårt (I), flummiga } \\
\text { instruktioner (I), } \\
\text { tilltala läsaren (I) }\end{array}$ \\
\hline Totalt: 19 st. & Totalt: 18 st. & Totalt: 16 st. & Totalt: 9 st. & Totalt: 20 st. \\
\hline
\end{tabular}

Det vanligaste återkommande svaret beskriver källhantering (angett av $23 \%$ ). En student uttrycker det som "att formulera om så det inte blir för 'kopierat" och bekräftar därmed att hen inte har förstått vad det innebär att referera, medan andra studenter framhäver "reglerna kring hur det ska se ut” och snarare tycks åsyfta referenssystem än själva referatet. En annan återkommande upplevd svårighet rör struktur och tydlighet (angett av 2I \%), vilket ofta formuleras som sammanhang, struktur eller röda tråden. Det finns också svar som rör textens längd där vi tolkar det som att svårigheten är kopplad till struktur och överskådlighet i längre text. En tredje svårighet som många nämner rör språklig formulering (20\%). Ofta lyfter studenterna mer specifikt fram ordval, medan bara enstaka lyfter fram grammatik och meningsbyggnad. En person uttrycker denna svårighet såhär: "Rätt. Att formulera sig rätt. Att använda sig av rätt ord.” och tydliggör därmed svårigheten i att få det egna språkbruket att passa in i en upplevd språknorm. En fjärde svårighet rör hur man som skribent ska förhålla sig till innehållet (angett av II \%), där det som upplevs svårt kan vara alltifrån analyserande och djup till objektivitet och saklighet. Därutöver förekommer en mängd övriga svar. Här kan ytterligare semantiska kategorier urskiljas men dessa representeras endast av ett fåtal svar, såsom akademiskt/vetenskapligt ( 5 svar), kreativitet/komma igång (5 svar) och specifika texttyper/skrivsätt (3 svar). 


\section{Emilia Sturm Aldrin et al.}

Ett mönster som framkommer är att de studenter som tidigare i enkäten svarat att de generellt inte är så bra på att skriva i första hand nämner struktur och tydlighet som svårt (6 av I5 st.). Studenter som istället svarat att de generellt är bra på att skriva framhäver i högre grad referensteknik (IO av 39 st.), språklig formulering (8 av 39 st.) samt förhållningssätt till innehåll (7 av 39 st.) som svårigheter, men mer sällan struktur och tydlighet ( 5 av 39 st.). Materialets begränsade omfång förhindrar långtgående slutsatser av detta, men indikerar att studentens generella skrivkompetens kan ha betydelse för vilka svårigheter man upplever med det akademiska skrivandet. Studentens kön och ålder ger inga statistiskt signifikanta mönster.

\section{DISKUSSION}

Eftersom ungefär hälften av studenterna uttrycker ett positivt känslomässigt förhållningssätt till skrivande generellt och nästan hälften har god tilltro till den egna skrivförmågan tyder detta på att många har en positiv underliggande attityd till skrivande, vilket tidigare forskning (Graham, 2006; Graham, Daley, Aitken, Harris \& Robinson, 2018) identifierat som en viktig förutsättning för motivation till skrivutveckling. Intressant är att betydligt fler kvinnor än män uttrycker ett positivt känslomässigt förhållningssätt till skrivande generellt, vilket enligt Troia, Shankland och Wolbers (20I2) är ett förhållande som i internationella studier endast framkommer bland yngre elever (där skrivande betraktas som en feminin aktivitet) och inte kvarstår på högskolenivå. Vi har också sett att de äldsta studenterna uttrycker en mer positiv inställning till skrivande generellt och har den högsta andelen som upplever sig ha förändrat sitt skrivande "mycket" efter högskolestarten. Ålder tycks inte ha undersökts mycket i detta sammanhang tidigare, men våra resultat indikerar att denna variabel möjligen borde undersökas mer i framtida studier om skrivmotivation på högskolenivå.

Det är en relativt stor andel av deltagarna i denna studie (4I \%) som uttrycker att de vare sig "tycker om" eller "inte tycker om" att skriva. De uttrycker därmed inget affektivt förhållningssätt till skrivande. En möjlig förklaring till detta kan vara att de inte ser skrivande i första hand som ett mål i sig som man kan utveckla ett känslomässigt förhållningssätt till, utan snarare som ett neutralt verktyg för andra mål (såsom att klara studierna). För att validera detta skulle krävas ytterligare undersökningar. Däremot är det mycket få av de nyantagna studenterna som uttrycker ett negativt förhållningssätt till skrivande generellt ( 5 st.) och relativt få som uttrycker låg tilltro till den egna skrivförmågan ( $15 \mathrm{st}$.). Detta är betydligt färre än vad som identifierats i tidigare liknande studier. Gardner (20I4) fann exempelvis att nästan hälften av studenterna uttryckte en negativ inställning till skrivande i början av sin utbildning, även om andelen minskade under utbildningens gång. Noterbart är också att majoriteten av studenterna som uttrycker en negativ attityd till skrivande eller har låg tilltro till den egna skrivförmågan i vår studie är män (jfr Troia, Shankland \& Wolbers, 20I2).

Studenternas bild av vad det innebär att "skriva akademiskt" vid studiens genomförande ett par veckor in på terminen är variationsrik och i många fall oklar. Ändå uppger majoriteten att de redan förändrat sitt sätt att skriva i någon mån. Detta tyder på att studenterna mycket tidigt efter högskolestarten blir medvetna om att det finns specifika textnormer och särskilda krav på språkhantering - även om det fortfarande upplevs oklart vad dessa innebär - och att de upplever att de snabbt börjar utforska dessa nya former i sitt eget skrivande. Svaren implicerar vikten av att tidigt tydliggöra för studenterna vilka förväntningar som finns på deras skrivande i olika utbildningssammanhang. Resultatet tydliggör också den komplexa samverkan mellan olika attitydkomponenter (Garrett, 20IO). Däremot har den här studien inte undersökt i vilken 
mån studenter med olika förhållningssätt använt olika strategier för sin språkutveckling eller blivit olika framgångsrika, vilket kunde vara en intressant fråga för fortsatt forskning.

Till skillnad från en del tidigare forskning (Ask, 2005b) märks i denna studie ingen skillnad mellan hur många eller vilka svårigheter som upplevs av kvinnor respektive män. I förhållande till den så kallade texttriangeln (Dysthe, Hertzberg \& Hoel, 20II, s. 4I), som beskriver hur arbetet med att skriva en text pågår på olika nivåer med olika progression mellan dessa nivåer, ser vi att studenternas svar tar fasta på såväl globala nivåer av skrivandet, vilka påverkar hela texten (förhållningssätt till innehåll samt struktur och tydlighet), som lokala nivåer, vilka aktualiseras på enskilda ställen i texten (stilnivå och annan språklig formulering samt källhantering). De semantiska fälten visar också likheter med forskningens försök att definiera den vetenskapliga prosastilen. Jarrick och Josephson (I996, s. 24) har lyft fram opersonlighet, precision, koncentration och organisation som viktiga kännetecken. Ask (2007, s. 16) har utifrån en bred forskningsbakgrund pekat på dess prägling av kritisk analytisk kompetens, akademiska textkonventioner och lyhördhet för stil- och skriftspråkskonventioner. Studenternas svar i denna studie kan knytas till samma dimensioner. Tillsammans uttrycker de nyantagna studenterna således en relativt komplex förståelse för det akademiska skrivandet. Vår lokala studie både bekräftar tidigare forskning samtidigt som den ger mer differentierat underlag genom identifikationen av semantiska fält bland studenternas konnotationer och såväl samband som diskrepans mellan det man uppfattar som mest typiskt för akademiskt skrivande och det man uppfattar som mest svårt. Medan källhantering bara påtalas av ett fåtal studenter som det främsta kännetecknet för akademiskt skrivande är det samtidigt det vanligaste området för upplevda svårigheter. Omvänt är det många som lyfter skribentens förhållningssätt till innehållet som typiskt för akademiskt skrivande, men få ser det som den främsta svårigheten. Vi har också noterat att de upplevda svårigheterna tycks samverka med graden av tilltro till den egna skrivförmågan, vilket inte uppmärksammats tidigare. Framför allt tycks studenter med låg tilltro till den egna skrivförmågan uppleva fler svårigheter med struktur och tydlighet än andra, vilket vi ser som viktigt att vara medveten om vid utformandet av fortsatta språkstöttande moment.

När studenterna anger ord som uttrycker stilnivå är det påfallande många ord som innehåller en negativ värdeladdning, såsom stelt, krångligt, svårordigt och pretentiöst. Vi tolkar detta negativt laddade ordval som att dessa studenter uppfattar att den akademiska stilnivån ligger långt från det egna språkbruket. Det kan därför vara uttryck för den "diskurschock" som Ask (2005a) beskrivit. Att det akademiska språket upplevs distanserat kan också anas av andra formuleringar i studenternas svar såsom ej vardagligt, ingen slang och omformulera meningar. Sköldvall, Rising och Danielsson (20I7, s. 227) beskriver än mer negativa associationer till akademisk text bland nya studenter på polisutbildningen (t.ex. "en tvångströja", "mycket ord utan att få något sagt") och uppfattar det som att studenterna trott att de akademiska texternas svårtillgänglighet är ett självändamål och känt sig hindrade av att inte kunna använda sitt vanliga språk. Även om lika starkt negativa formuleringar inte förekommer här, är det tydligt att många studenter inte förstår varför det specifika språkbruket är viktigt. Man har ännu inte knäckt koden att ämnesspecifika termer och begrepp bidrar till ökad ämnesspecifik förståalse och förenklar snarare än försvårar. Samtidigt tydliggörs ett klass- och identitetsperspektiv. Preece (2018) menar att både klass och genus kan få betydelse för hur studenter uppfattar akademisk diskurs som prestigefylld och distanserad från dem själva. Enligt Ryan, Giles och Sebastian (1982) påverkas värderingen av språkliga uttryck ofta av känslan av grupptillhörighet och solidaritet (eller avsaknaden av detta) i förhållande till den grupp som förknippas med språket. Vi har inte undersökt enkätdeltagarnas klasstillhörighet, men studenternas konnotationer i denna studie visar att det 


\section{Emilia Sturm Aldrin et al.}

akademiska skrivandet förknippas med specifika identiteter. Uttryck som stelt, pretentiöst, fina ord och politiskt korrekt bekräftar att det akademiska språket kan förknippas med högstatusgrupper i samhället, vilket betonats i tidigare forskning (se t.ex. Preece, 20I8). Svaren professionella ord, smart, vuxet och ordentligt antyder dock även ytterligare sociala identiteter som studenterna förknippar med det akademiska språket och fler identitetsomvandlingar som de tror kan krävas för att tillägna sig detta språk. Här framgår att det akademiska språket också förknippas med vuxenidentitet och yrkesprofessionalitet. Att utveckling av akademiskt skrivande kan upplevas som en del i vuxenblivandet har inte uppmärksammats tidigare. Betydelsen för utvecklingen av en yrkesprofessionalitet är däremot väl belagd. Erixon och Erixon Arreman (2019) menar att det akademiska skrivandets relevans för professionen kan vara särskilt viktigt i (förskol-)lärarutbildning. Enligt Arneback, Englund och Dyrdal Solbrekke (2016) är det dock inte alltid studenterna ser denna koppling så tydligt i början av utbildningen som har visat sig här. Möjligen antyder dessa svar också studenternas förhållningssätt till den undervisande personalen vars akademiska språkbruk de möter kontinuerligt i vardagen. Utifrån ett sådant resonemang - och med tanke på att människor är mer sannolika att anpassa sitt språk efter grupper som de är positiva till (Ryan, Giles \& Sebastian, 1982) - blir det än viktigare att det utvecklas goda relationer mellan undervisande lärare och studenter.

\section{AVSLUTNING}

Vi har i denna artikel undersökt förhållningssätt till skrivande generellt, skriftspråket på högskolan och den egna skrivkompetensen bland nyantagna lärarstudenter vid ett mindre lärosäte med socioekonomiskt varierad upptagning. Graham, Daley, Aitken, Harris \& Robinson (20I8) har argumenterat för att motivationen till skrivutveckling påverkas av individens förhållningssätt och menar att en generellt positiv inställning till skrivande och framför allt en hög grad av tilltro till den egna skrivförmågan - vilket vi sett här - utgör en god förutsättning för att studenter ska kunna utveckla de färdigheter inom akademiskt skrivande som är nödvändiga för att de ska klara högskoleutbildningen. Förhållningssättet till skriftspråket på högskolan visade sig vara varierat och aktualiserade frågor om det akademiska skrivandets olika dimensioner och hur de upplevs av nya studenter, men också om studenternas syn på identitet och grupptillhörighet. Eftersom dessa sociala processer också är betydelsefulla för utvecklingen av färdigheter inom akademisk kommunikation (Duff, 20IO; Lillis, Harrington, Lea \& Mitchell, 2016) behövs kunskap om studenternas utgångspunkter i dessa processer för att kunna utforma effektiv språkutvecklande stöttning.

Med utgångspunkt $\mathrm{i}$ studiens resultat kommer vår fortsatta planering av skrivstöttande moment inom ämneslärarutbildningen att inkludera: fortsatt genomförande av denna typ av enkät som uppmanar studenterna till explicit reflektion över sitt förhållningssätt till skrivande (jfr Gardner, 20I4), blandade åldersgrupper som sprider ut de äldsta studenterna, systematiska workshoppar kring vad akademiskt skrivande innebär inom olika discipliner (jfr Malmbjer, 20I7) som anknyter till de frekvent upplevda svårigheterna med källhantering, struktur och tydlighet i det akademiska skrivandet. Trots sitt begränsade omfång har studien bidragit till forskningen om akademisk skrivutveckling genom att peka på nya faktorer som inte tidigare uppmärksammats. Betydelsen av ålder och vuxenblivande samt studentens tilltro till den egna skrivförmågan visade sig vara viktiga processer i samband med utvecklingen av kompetenser inom akademiskt skrivande och skulle behöva undersökas mer i fortsatta studier på området. Detta är särskilt viktigt relativt breddat deltagande och ett mer demokratiskt tillträde till högre utbildning. 


\section{FÖRFATTARPRESENTATION}

Emilia Sturm Aldrin är lektor i svenska språket och verksam inom ämneslärarutbildningen i svenska på Högskolan i Halmstad. Hennes forskning befinner sig främst inom sociolingvistiken med särskilt fokus på språkligt identitetsskapande.

Monica Eklund är lektor i utbildningsvetenskap och verksam inom ämneslärarprogrammen vid Högskolan i Halmstad. Hennes forskning fokuserar bland annat på hur studenter med olika bakgrunder knäcker de akademiska koderna samt på nyanländas lärande.

Heike Peter är lektor i religionsvetenskap och verksam inom ämneslärarprogrammen vid Högskolan i Halmstad. Hennes forskning berör bland annat ritualer, religionsundervisningen och nyanländas lärande inom ämneslärarutbildningen.

\section{REFERENSLISTA}

Arneback, E., Englund, T. \& Dyrdal Solbrekke, T. (2016). Writing in and out of control. A longitudinal study of three student teachers' experiences of academic writing in preschool teacher education. Nordic Studies in Education 36, 211-228.

Ask, S. (2005a). Akademisk skriftspråkskompetens i praktiken. Studenter möter universitetets textvärldar. I M. Lindgren (Red.), Den skrivande studenten. Idéer, erfarenheter och forskning frän Textverkstaden vid Växjö universitet (s. 88-100). Växjö: Växjö Universitet.

Ask, S. (2005b). Röster i övergången. Studenter om skrivandet i högre utbildning. I M. Lindgren (Red.), Den skrivande studenten. Idéer, erfarenheter och forskning frän Textverkstaden vid Växjö universitet (s. 101-117). Växjö: Växjö Universitet.

Ask, S. (2007). Vägar till ett akademiskt skriftspråk. Diss. Växjö: Växjö universitet.

Ask, S. \& Sandblad, F. (2003). Stadieövergångar och textvärldar. Om nyblivna studenter som möter högskolans textvärld. HumaNetten, 12.

Duff, P. (2010). Language Socialization into Academic Discourse Communities. Annual Review of Applied Linguistics, 30, 169-192.

Dysthe, O., Hertzberg, F. \& Hoel Løkensgard, T. (2011). Skriva för att lära. Skrivande i högre utbildning. Lund: Studentlitteratur.

Erixon, P.-O. \& Erixon Arreman, I. (2019). ECEC Students' Writing Trajectories: Academic Discourse and "Professional Habitus". Scandinavian Journal of Educational Research 63:6, 968-983.

Gardner, P. (2014). Becoming a teacher of writing: Primary student teachers reviewing their relationship with writing. English in Education 48:2, 128-148.

Garrett, P. (2010). Attitudes to language. Cambridge: Cambridge University Press.

Graham, S. (2006). Writing. I P. Alexander \& P. Winne (Red.), Handbook of educational psychology (s. 547-478). Mahwah, NJ: Erlbaum.

Graham, S., Daley, S., Aitken, A., Harris, K. \& Robinson, K. (2018). Do writing motivational beliefs predict middle school students' writing performance? Journal of research in reading 41:4, 642-656.

Jarrick, A. \& Josephson, O. (1996). Från tanke till text. En språkhandbok för uppsatsskrivande studenter. Lund: Studentlitteratur.

Kristiansen, T. (2009). Åbne og skjulte holdninger till engelskindflydelsen - hvad kan sprogpolitikken påvirke? Språk i Norden, 2009, 95-112.

Lillis, T., Harrington, K., Lea, M. \& Mitchell, S. (Red.), (2016). Working With Academic Literacies: Case Studies Towards Transformative Practice. Perspectives on writing. Fort Collins, Colorado: The WAC Clearinghouse/Parlor Press.

Malmbjer, A. (2017). Skriva i alla ämnen: En forskningsöversikt. I A. Malmbjer (Red.), Studenters skrivande i humaniora och sambällsvetenskap (s. 13-53). Södertörn: Södertörns högskola.

Middendorf, J. \& Pace, D. (2004). Decoding the Disciplines: A Model for Helping Students Learn Disciplinary Ways of Thinking. New Directions for Teaching and Learning, 98, 1-13. 


\section{Emilia Sturm Aldrin et al.}

Preece, S. (2018). Identity work in the academic writing classroom: Where gender meets social class. Journal of English for Academic Purposes, 32, 9-20.

Ryan, E., Giles, H. \& Sebastian, R. (1982). An integrative perspective for the study of attitudes toward language variation. I E. Ryan \& H. Giles (Red.), Attitudes towards language variation (s. 1-19). London: Edward Arnold.

Sköldvall, K., Rising, C. \& Danielsson, M. (2017). "Får man säga att det känns hopplöst?” - Polisstudenter möter det akademiska skrivandet. I A. Malmbjer (Red.), Studenters skrivande i humaniora och samhällsvetenskap (s. 215-236). Södertörn: Södertörns högskola.

Tapp, J. (2014). "I actually listened, I'm proud of my self" The effects of a participatory pedagogy on students' constructions of academic identities. Teaching in Higher Education, 19. DOI:10.1080/ 13562517.2013.860108.

Troia, G., Shankland, R. \& Wolbers, K. (2012). Motivation research in writing: theoretical and empirical considerations. Reading \& Writing Quarterly 28:1, 5-28.

Universitetskanslerämbetet. (2018). Tidiga avhopp frän högskolan. Analyser av genomströmning på de tio största yrkesexamensprogrammen. Rapport 2017:17. Stockholm: Universitetskanslerämbetet.

Walker, M. (2006). Higher education pedagogies: A capabilities approach. New York: Society for research into higher education. 